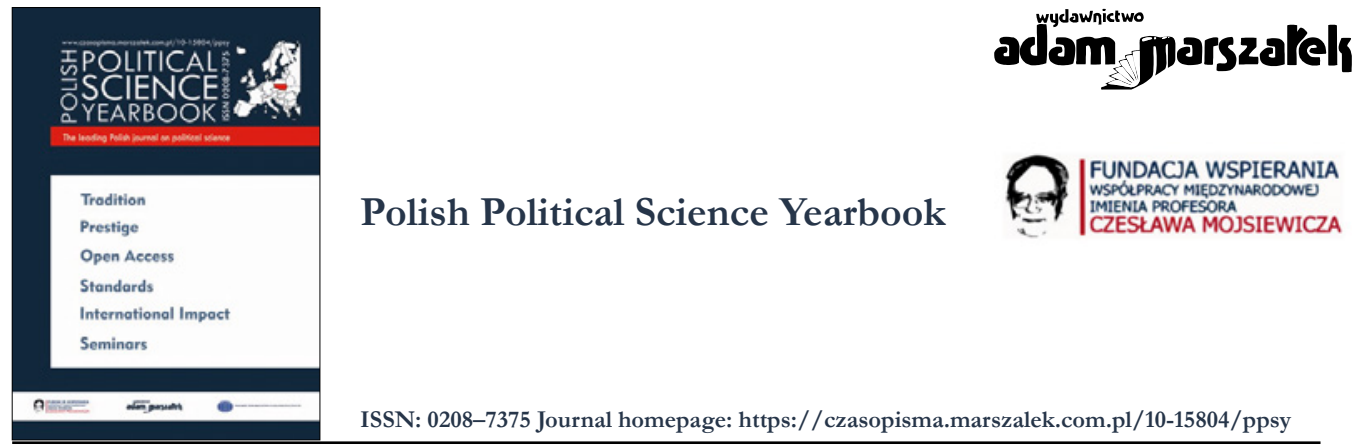

\title{
United Nations' Sustainable Development Goals and the Most Important Utilitarian Values. Social Security Approach
}

Paweł Gromek ${ }^{1}$, Tadeusz Kęsoń ${ }^{2}$

ORCID: 0000-0003-0997-5069' $10000-0002-7047-7811^{2}$

To cite this article please include the following information:

- Journal title: Polish Political Science Yearbook

- Volume number: 50

- Year of publication: 2021

- Published ahead-of-print

Example styles:

[APA Style]: Gromek, P., Kęsoń, T. (2021). United Nations' Sustainable Development Goals and the Most Important Utilitarian Values. Social Security Approach. Polish Political Science Yearbook, 50(issue number), pages. https://doi.org/10.15804/ppsy202146

[Chicago Style]: Paweł Gromek, Tadeusz Kęsoń, “United Nations’ Sustainable Development Goals and the Most Important Utilitarian Values. Social Security Approach" Polish Political Science Yearbook 50, no. [issue number] (2021).

To link to this article: https://doi.org/10.15804/ppsy202146

Published ahead-of-print

Final submission: 17 September 2021

Published online: 2 November 2021

Printed issue: 2021

Submit your article to PPSY 


\title{
Pawel Gromek
}

Main School of Fire Service

ORCID: 0000-0003-0997-5069

e-mail: pgromek@sgsp.edu.pl

\section{Tadeusz Kęsoń}

Main School of Fire Service

\section{United Nations' Sustainable Development Goals and the Most Important Utilitarian Values. Social Security Approach}

\begin{abstract}
Agenda constitutes a comprehensive framework for sustainable development. Nevertheless, not all sustainable development goals properly match the most important utilitarian values (human life and health). It is especially noticeable in terms of disasters and crises, which commonly determine social security. The research objective is to indicate the placement of the values in the particular goals. The systematic literature review indicates 47 information sources. That enables an in-depth analysis of the goals and social security specification elements, highlighting the direct or indirect character of relevant relations. The gaps can be identified considering the social character of the goals, characteristic hazards, danger to human life, and health and urgency of the response. In most cases, the relations between the goals and the values are indirect. They can be improved with a potentially positive influence on sustainable development in all circumstances (including the most dangerous ones). The goals specification states many references for the improvement in a synergistic way respecting the most important utilitarian values, especially in zero hunger, good health and well-being, sustainable cities and communities, climate action, partnership for the goals.
\end{abstract}

Keywords: sustainability, sustainable development goal, SDGs, security, social security 


\section{Introduction}

Sustainability is connected with many security-related issues. Swensson and Tartanac (2020) highlight its usefulness in food security studies when implemented into public food procurement, diets, and food system challenges. It can influence food security via the relevant certification process (Schleifer \& Sun, 2020). Because of the long-term specification, it is said to be a trusted operational direction for energy security, serving complex catalogs of indicators (Richards \& Zaili, 2020). Similarly to emergency management (Nuta \& Ciortan, 2015), when sustainable rescue ability can support logistics in cascading effect conditions and network infrastructure connections (Zhang et al., 2019), sustainable emergency planning can be ascribed to civil planning in modern due to multiple disasters (e.g., earthquakes) (Bernardini et al., 2020). Disasters can be used as sustainability opportunities in, at least, recovery processes in housing, worshipping, eating, being mobile, working, educating, recreating, caring, engaging, and communicating (Brundiers, 2018). Sustainable development generates new kinds of threats, and cyberspace is an extremely important source of them (Stergiou et al., 2018; Mohandes et al.,2018). Nevertheless, cybersecurity can be built sustainably and supported by sustainable ideas (Celdran et al., 2018).

The conceptual connection between sustainability and security can be presented more comprehensively. Roostaie et al. (2019) highlight a close relation between sustainability and resilience and use these concepts to find novel resilience indicators and frameworks. Fennelly \& Perry (2020) show that the cultural layer of security may be created using sustainability patterns and manners. Knowledge integration and multi-actor governance can be understood as two risk management directions in the context of governance for sustainability (Shiroyama et al., 2012; Siemiątkowski et al., 2020), and systemic approach, so much characteristic for security studies, is implemented to sustainability research in case of natural disasters (Shahbazbegian \& Bagheri, 2010).

Different approaches for sustainability caused a necessity to elaborate the comprehensive one, linking all most important issues of sustainability and sustainable development, however, not only in the security context. United Nations (UN) has responded to the need, and the 2030 Agenda for Sustainable Development (2030 Agenda) was agreed in 2015. The Agenda marks 17 Sustainable Development Goals (SDGs) (Report, 2016).

Many scientists have been carrying out their research on SDGs implementation since 2015. In general, the research work can be divided into three groups of output. The first group concerns studies for particular SDGs (or relevant targets) application (Mulligan et al., 2020; Witt et al., 2020). The second one comprises SDGs-related case studies for different countries, paying special attention to the developing ones (Horn \& Grugel, 2018; Kumi et al., 2020). The third group collects works dedicated to multiple sustainability contexts (for example, urban targets (Rozhenkova et al., 2019), SDGs prioritizing (Allen et al., 2019), indicators (Barbier \& Burgess, 2019), humanitarian aid (Mary \& Mishra, 2020) and interconnection between the goals (Swain \& Ranganathan, 2021)). 
All the works imply different social values to be commonly protected in the light of the 2030 Agenda (Massenberg, 2019; Odii et al., 2020) and correspond to, more or less directly, security issues. As far as the values are concerned, it is hard to prioritize them because the agenda reflects a holistic view of world development. Theoretically (from the agenda point of view), all of them are equally important. Practically, natural hazards and man-made events prove that human life and health (as well as property and environment but only in terms of human basic existence needs) should be marked with the highest priority of importance. In conditions of direct danger to human life, the social character of the negatively perceived events, their urgency, and characteristic circumstances (hazards), these values are generally above the others, even in a sustainability context (Busby et al., 2018; Gromek \& Sobolewski, 2020). They are the most important utilitarian ones, but SDGs seem to ignore this argument, even with many security-related connections to sustainability. It is a serious gap because sustainable development should respect that some values are more important than others (sustainable does not mean equable).

The most important utilitarian values commonly state a core element of social security (Rhinard, 2007). According to The Copenhagen School of Security Studies, it can be defined as "the ability of a society to persist in its essential character under changing conditions and possible or actual threats. More specifically, the concept is about the sustainability, within acceptable conditions for evolution, of traditional patterns of language, culture, association, and religious and national identity and custom" (Wæver \& Buzan, 1993; Hoyland, 2018). Wolanin (2017) relates it with natural disasters and man-made events, which force multiple agencies and services to enhance effective response to hazards, civil protection, critical infrastructure protection, and manage relevant operations. Social security is strongly related to risk (understood as safety and security measures). And the wide agencies involvement is characteristic also for sustainability development (Manby, 2021).

Respecting the most spectacular hazards associated with disasters and a direct connection with sustainability justify a reason why social security can be cognitively used to investigate the placement of human life and health in the 2030 Agenda. Therefore, the objective of this study is to indicate the placement by analysis of particular SDGs in the context of social security. Thereby, we would like to collect information that will allow us to face the identified gap - an indirect reference of SDGs to the values that are undoubtedly the most important in all circumstances and conditions, for mostly all social groups and societies nowadays and in the future.

\section{Materials and Methods}

A systematic literature review indicated direct and indirect connections of social security characteristic issues with particular SDGs. We used the Web of Science ${ }^{\circledast}\left(\mathrm{WoS}^{\circledast}\right)$ Core Collection database and a topic titled: "sustainable development goals and social security" to directly connect the two issues. Such a proceeding allowed us to consider all titles, abstracts, 
author keywords, and Keywords Plus from the database. No time limitations were placed (all years). We identified 47 literature positions as a solid framework for relations' identification. To achieve such a goal, it was necessary to focus only on SDGs and social security as wholes, disregarding fragmentary concepts, premises, and indicators that do not allow to visualize an entire picture of the research object.

In-depth analysis of the papers was directed into four crucial social security specification elements: social character, characteristic hazards, danger to human life and health, as well as the urgency of the response (Bodaghi et al., 2020; Gromek, 2020). The presence or absence of relations between the elements and SDGs in the literature highlighted areas to make additional theoretical and practical activities to improve mutual correspondence and strengthen a position of social security in sustainable development. Detailed results of the systematic literature review are presented in Appendix 1.

\section{Results}

\subsection{Social Character in SDGs}

The social character was the most often mentioned element in the analyzed papers. Table 1 presents particular aspects of the character which can be identified based on the paper's content. We highlighted SDGs which are connected with the aspects in the referenced papers.

Tab. 1 Results of the 'social character' analysis

\begin{tabular}{ll}
\hline An aspect of the social character & SDGs \\
\hline Social needs, goals, and objectives & $1,2,3,4,6,7,8,9,10,11,12,13,14,15,16,17$ \\
\hline Social drivers and indicators & $1,2,3,4,5,6,7,8,9,10,11,12,13,14,15,16,17$ \\
\hline $\begin{array}{l}\text { Social challenges (incl. access to common goods } \\
\text { and resources) }\end{array}$ & $1,2,3,4,5,6,7,8,9,10,11,12,13,14,15,16,17$ \\
\hline Social benefits of sustainable development & $2,3,4,6,7,9,12,13,15,16,17$ \\
\hline $\begin{array}{l}\text { Social cost and tradeoffs related to sustainable } \\
\text { development }\end{array}$ & $1,2,3,6,7,9,10,11,12,13,14,15,17$ \\
\hline Social values & $1,2,3,4,5,6,7,8,9,10,11,12,13,14,15,16,17$ \\
\hline Security and socisocialetal vulnerability & $1,2,4,5,7,8,10,11,12,13,14,15,17$ \\
\hline Social organization and transformation & $1,2,5,7,8,12,13,14,15,16,17$ \\
\hline Social improvement and development & $1,2,3,4,6,7,8,10,11,12,13,14,15,16,17$ \\
\hline Social involvement & $3,7,8,9,11,12,13,15,16,17$ \\
\hline General social character of issues & $1,2,3,5,9,10,12,13,17$ \\
\hline
\end{tabular}

The main attention is put on factors that determine general conditions and activities related to social effect (needs, goals, objectives, drivers, indicators, values). The social character is reflected by facilitators and inhibitors of the effect (mostly the economic ones) and current directions of its practical implementation (e.g., improvement, sustainable development, stakeholders' involvement). 
The aspects cover all SDGs. However, even if the social character is mentioned, it does not fully match social security. Social security touches all SDGs in terms of social character, but the relationship is mostly indirect.

\subsection{Characteristic Hazards in SDGs}

Social hazards delineate a context of operations to ensure social security. To match the cohesion of the security specification elements, we extended to the popular hazards catalog (UNDRR, 2020) and considered all kinds of hazards with the potential social effect. After the papers' analysis, we enumerated the hazards references in table 2. Furthermore, we indicated their connections with the SDGs.

Tab. 2 Results of the 'characteristic hazards' analysis

\begin{tabular}{ll}
\hline An aspect of the characteristic hazards & SDGs \\
\hline General direction on hazards and threats & $1,2,3,4,5,6,7,8,9,10,11,12,13,14,15,16,17$ \\
\hline Disaster (in general) & $1,2,3,4,5,6,7,8,9,10,11,12,13,14,15,16,17$ \\
\hline Climate change & $1,2,3,4,5,6,7,8,9,10,11,12,13,14,15,16,17$ \\
\hline Weather (extreme, adverse) & $1,2,3,5,6,7,8,11,12,13,14,15,16,17$ \\
\hline Flood and flooding & $1,2,3,4,5,6,7,8,9,10,11,12,13,14,15,16,17$ \\
\hline Drought & $1,2,3,5,6,7,8,9,10,11,12,13,14,15,16,17$ \\
\hline Fire & $2,3,7,8,11,12,13,14,15,17$ \\
\hline Disease (incl. epidemic and pandemic) & $1,2,3,4,5,6,7,8,9,10,11,12,13,14,15,16,17$ \\
\hline Conflicts and violence (incl. terrorism and organized crime) $)$ & $1,2,3,4,5,6,7,8,9,10,11,12,13,15,16,17$ \\
\hline Hazardous materials & $2,3,6,11,12,14,15$ \\
\hline Cyber threats & $4,6,7,9,13,15,16,17$ \\
\hline
\end{tabular}

The results prove that the SDGs implementation in the social security context may consider different, negatively perceived circumstances, in general (e.g., hazards, threats, disasters, climate change) and in particular (flood, fire, drought, etc.). Despite most hazards strictly refer to climate change and other sustainable development motivations, some of them are said to be derivative social security determinants (e.g., military conflicts, terrorism, cyber threats).

The hazards cover all SDGs. However, in opposition to the social character, the hazards strongly connect the goals to security issues as they express their general conditions and determine relevant operations.

\subsection{Danger to Human Life and Health in SDGs}

Danger to human life and health is specific to social security because it regards a common, particularly social character of the hazards influence (no matter of descent, social status, religion, pigmentation, etc.). Table 3 presents particular aspects identified in the literature analysis and ascribed to the SDGs. 
Tab. 3 Results of the 'danger to human life and health' analysis

\begin{tabular}{ll}
\hline An aspect of the danger to human life and health & SDGs \\
\hline Relation with the characteristic hazards & $1,2,3,4,6,7,8,10,11,12,13,14,15,16,17$ \\
\hline Direct impact on human life and health & $1,2,3,4,6,7,11,13,15,16,17$ \\
\hline $\begin{array}{l}\text { Indirect impact (incl. potential to imitate cascading effect of } \\
\text { hazards development) }\end{array}$ & $1,2,3,4,6,7,8,10,11,12,13,14,15,16,17$ \\
\hline $\begin{array}{l}\text { Relation with factors lowering a level of living (existence) } \\
\text { conditions (e.g., access to food, drinking water) }\end{array}$ & $1,2,3,4,6,7,8,10,11,12,13,15,16,17$ \\
\hline
\end{tabular}

Danger to human life and health is so evident in the context of social security and relatively hard to in-depth division that its analysis was problematic from a practical perspective. Nevertheless, focusing on the SDGs allowed to identify four aspects considered by the authors of the papers.

Almost all SDGs are covered. SDG5 and SDG9 are missed supposably due to their specification. Like in the case of the hazards (and in relation to them), the aspects strongly meet the security issues. Nevertheless, many papers prove that this element is significantly less mentioned in the literature than the previous two.

\subsection{Urgency of the Response in SDGs}

Even if sustainability is long-term oriented, the urgency of the response regards factors specific also for the conditions related to the SDGs (e.g., climate change consequences). Table 4 presents particular aspects concluded based on the literature review and ascribed to the SDGs.

Tab. 4 Results of the 'urgency of the response' analysis

\begin{tabular}{ll}
\hline An aspect of the response urgency & SDGs \\
\hline Urgent need of the response & $2,3,6,8,12,13,15,16,17$ \\
\hline Relation with the characteristic hazards & $1,2,3,4,6,7,8,10,11,12,13,14,15,16,17$ \\
\hline Emergency references & $1,2,3,6,10,11,12,13,15,16,17$ \\
\hline Involvement of first responders & $3,11,17$ \\
\hline
\end{tabular}

We named four aspects that should be highlighted in the context of the response urgency. Only SDG5 and SDG9 are not covered by this specification element. Moreover, the element is mentioned in the lowest number of papers. Considering its core importance for the social security understanding, this highlights a serious merit-related gap in the literature. 


\section{Discussion}

The systemic review indicates the distribution of particular SDGs in the literature. Some differences reflect multiple interests of researchers in the light of social security specification elements. The highest number of papers regards matters of SDG2, SDG13, and SDG17. It stems from conditions of the characteristic hazards as they could have their sources in climate change consequences and hunger. In addition, they often require a wide stakeholders' involvement and coordination of their common operations (Bouma, 2015). The rest of the SDGs are not comprehensively covered by the literature but could inspire sustainability research for social security. Quite interesting from this point of view is SDG11, which connects safety and resilience with sustainability and inclusiveness in accordance with cities and human settlements (Gheuens et al.,2019) as well as the goals related to other potential sources for the hazards (SDG6, SDG14, SDG15, and SDG16).

A very strong relationship is observed for the social character. The relation is noticed in nearly all of the papers. The following aspects turned out as the most perspective: social needs, goals and objectives, social drivers and indicators, social challenges, social values, improvement, and development. Authors indicated current world development trends, focusing on social improvement and development, social organization and transformation (Eliasson et al., 2019; Yadav et al., 2020). It justified that the social character seems obvious, perspective, sustainability issue in the social security context.

We noticed an influence on the most important utilitarian values when characteristic hazards were analyzed. The hazards' references can be divided into general (general direction on hazards and threats, disaster, climate change) and particular (extreme or adverse weather, flood and flooding, drought, fire, disease, conflicts and violence, hazardous materials, and cyber threats). In all cases, the social character of their impact is identified. Climate change is undoubtedly the most severe hazard and source of the derivative ones (e.g., extreme weather, flood, drought) (Gheuens et al., 2019; Rao et al., 2019). That is why it connects many SDGs into one, social security background. There was highlighted that the SDGsrelated hazards have the potential to exceed coping society abilities. Understanding them as disasters opens for many ways to sustain human life and health (e.g., 2030 Agenda). We noticed that researchers interest matches current social security challenges. It justifies why so many papers deal with diseases and their epidemic (pandemic) potential. Nevertheless, as we used a broad analytical framework for the hazards investigation, the results are not limited to the UNDRR catalog of social hazards (armed conflicts, civil unrest, explosive remnants of war, environmental degradation from conflict, violence, stampede or crushing, financial shock) (UNDRR, 2020). It motivates further discussion about the need to collect all social-oriented hazards into one meaning category (e.g., branch of safety or security) to inspire theorists and practitioners to protect human life and health in danger, regardless of circumstances, especially when the hazards analysis covers all SDGs. 
Danger to human life and health seems to be the core element of the social security specification. However, it is not obvious in terms of sustainable development. It does not correspond to SDG5 and SDG9, which could result from the goals' scope. Nevertheless, the analysis results indicate cognitively interesting directions for further analysis (e.g., cascading effect, lowering a level of living or even existence conditions). They constitute this element, next to the relation with the characteristic hazards, direct or indirect impact on human life and health, and the relation with the factors lowering the level of living (existence) conditions (e.g., access to food, drinking water).

The same coverage of SDGs (all goals without SDG5 and SDG9) is observed in the urgency of the response. It has a background in relation with the characteristic hazards, as there is no time for delays in the conditions of floods, wildfires, etc. and is determined by emergency references (state of emergency, emergency management, etc.) (Kakkar et al., 2014) and also ascribed to the long-term political decisions and approaches for sustainable development (Al-Saidi, 2017). Even if this specification element deals with SDG17 (cooperation matters), it regards emergency first responders in a very limited way. This gap could be relatively quickly filled by the critical implementation of other SDG17 approaches and solutions, increasing capabilities to protect human life and health in different (not only emergency) circumstances.

Summarizing the results, there are three significant trends to be mentioned. Firstly, the more universal the social security specification element is, the more SDGs it covers, and the more links to sustainable development can be identified (more SDGs and more papers). Secondly, the goals are formulated at the high level of generality, and their meaning contexts are connected. Thus, the following exemplary connections are noticed in the social security background: SDG1 with SDG16, SDG2 with SDG15, SDG4 with SDG 9, SDG6 with SDG 14, SDG7 with SDG13, SDG7 with SDG15. It corresponds with a general impression about the network structure of the SDGs (Scharlemann et al., 2020; Dolley et al., 2020) and is specific for the area of interest (Gheuens et al., 2019). Thirdly, despite SDGs connections and universalism of some of the elements, we can mark gaps in relations between social security and SDGs. Table 5 presents a view of them.

Tab. 5 Matrix with the analysis results

\begin{tabular}{lllll}
\hline SDGs & $\begin{array}{l}\text { Danger to human } \\
\text { life and health }\end{array}$ & Social character & Response urgency & $\begin{array}{l}\text { Characteristic } \\
\text { hazards }\end{array}$ \\
\hline SDG1 & D/ID & D/ID & D/ID & D/ID \\
\hline SDG2 & D/ID & D/ID & ID & D/ID \\
\hline SDG3 & D/ID & D/ID & ID & D/ID \\
\hline SDG4 & D/ID & D/ID & ID & D/ID \\
\hline SDG5 & - & D/ID & - & D/ID \\
\hline SDG6 & D/ID & D/ID & ID & D/ID \\
\hline SDG7 & D/ID & D/ID & ID & D/ID \\
\hline
\end{tabular}




\begin{tabular}{lllll}
\hline SDGs & $\begin{array}{l}\text { Danger to human } \\
\text { life and health }\end{array}$ & Social character & Response urgency & $\begin{array}{l}\text { Characteristic } \\
\text { hazards }\end{array}$ \\
\hline SDG8 & D/ID & D/ID & ID & D/ID \\
\hline SDG9 & - & D/ID & - & D/ID \\
\hline SDG10 & ID & D/ID & ID & D/ID \\
\hline SDG11 & D/ID & D/ID & ID & D/ID \\
\hline SDG12 & ID & D/ID & ID & D/ID \\
\hline SDG13 & D/ID & D/ID & ID & D/ID \\
\hline SDG14 & ID & D/ID & ID & D/ID \\
\hline SDG15 & D/ID & D/ID & ID & D/ID \\
\hline SDG16 & D/ID & D/ID & ID & D/ID \\
\hline SDG17 & D/ID & D/ID & ID & D/ID \\
\hline
\end{tabular}

Gaps concerning SDG5 and SDG9 are noticeable. Most of the relations with the response urgency are indirect. Just like in SDG10, SDG12, and SDG14, due to danger to human life and health.

\section{Conclusions}

The most important utilitarian values are human life and health. They are widely, directly and indirectly, placed in the sustainable development agenda. Particular SDGs find their expression in elements of the social security specification (social character, characteristic hazards, danger to human life and health, urgency of the response).

The social character of the security in terms of sustainability is noticeable in the needs, goals and objectives, drivers and indicators, challenges, benefits, cost and trade-offs, values, vulnerabilities, stakeholders' involvement, social organization and transformation, social improvement and development. All these aspects prove that the SDGs are society-oriented, and everybody deserves to benefit from sustainable development results, regardless of geographical region, skin color, religion, gender, etc.

In case of the characteristic hazards, the goals are described in the context of a flood, flooding, fire, drought, disease, conflicts and violence, hazardous materials, cyber threats, and other kinds of hazards related to climate change, natural environment, and disasters. The primary factor is climate change which could initiate cascading effect of the hazards' development and the derivate hazards. The SDGs are related to the hazards' specification (e.g., SDG1 and SDG2 to violence, SDG13 with floods and droughts).

Danger to human life and health can be described in relation to the characteristic hazards, the character of impact on the most important values (direct or indirect), and relation with factors lowering a level of living (existence) conditions. That forces to investigate the social security and SDGs using a broad spectrum of life, living and existence conditions, and 
creates many areas of common, simultaneous achievement of the goals. It concerns mostly all SDGs (without SDG5 and SDG9).

Considering the urgency of the response, four aspects should be enumerated. There are urgent needs of the response (not limited to the emergencies but concerning also immediate prevention operations), of relation with the characteristic hazards, of emergency references (state of the emergency, emergency management, etc.), and involvement of first responders (mostly public administration and public services). It is regarded to the SDGs just like in the case of the previous element.

In addition, the review highlighted gaps identified for SDG5 and SDG9 (in relation to danger to human life and health and the response urgency) and the response urgency and danger to human life and health.

Summing up, the aspects named for the social security specification in its correspondence to the SDGs can serve as cognitive structures for further research and practical efforts for sustainable development, just like information about the gaps, especially when more detailed topics can be used to explore the literature (e.g., 'disaster,'sustainability','flood,' human life',human security') and formal or quasi-formal catalogs of hazards can be considered (e.g., UNDRR).

\section{References:}

Allen, C., Metternicht, G., \& Wiedmann, T. (2019). Prioritising SDG targets: assessing baselines, gaps and interlinkages. Sustainability Science, 14, 421-438. https://doi.org/10.1007/s11625-018-0596-8

Alrøe, H.F., Moller, H., Læssøe, L., \& Noe, E. (2016). Opportunities and challenges for multicriteria assessment of food system sustainability. Ecology and Society, 21(1), 38. http://dx.doi.org/10.5751/ ES-08394-210138

Al-Saidi, M. (2017). Conflicts and security in integrated water resources management. Environmental Science and Policy, 73, 38-44. http://dx.doi.org/10.1016/j.envsci.2017.03.015

Arias, M.E., Holtgrieve, G.W., Ngor, P.B., Dang, T.D., \& Piman, T. (2019). Maintaining perspective of ongoing environmental change in the Mekong floodplains. Current Opinion in Environmental Security, 37, 1-7. https://doi.org/10.1016/j.cosust.2019.01.002

Barbier,E.B., \& Burgess, J.C. (2019). Sustainable development goal indicators: Analyzing trade-offs and complementarities. World Development, 122, 295-305. https://doi.org/10.1016/j.worlddev.2019.05.026

Bedunah, D.J., \& Angerer, J.P. (2012). Rangeland Degradation, Poverty, and Conflict: How Can Rangeland Scientists Contribute to Effective Responses and Solutions? Rangeland Ecol Manage, 65, 606-612. https://doi.org/10.2111/REM-D-11-00155.1

Bernardini, G., Lucesoli, M., \& Quagliarini, E. (2020). Sustainable planning of seismic emergency in historic centres through semeiotic tools: Comparison of different existing methods through real case studies. Sustainable Cities and Society, 52, 101834. https://doi.org/10.1016/j.scs.2019.101834

Bhaduri, A., Bogardi, J., Siddiqi, A., Voigt, H., Vörösmarty, C., Pahl-Wostl, C., Bunn, S.E., Shrivastava, P., Lawford, R., Foster, S., Kremer, H., Renaud, F.G., Bruns, A., \& Osuna, V.R. (2016). Achieving Sustainable 
Development Goals from a Water Perspective. Frontiers in Environmental Science, 4, 64. https:// doi.org/10.3389/fenvs.2016.00064

Bitso C., Makori E.O., \& Kapondera S.K. (2020). Research Data Management and Scientific Evidence: A Strategic Imperative for SDGs. In M. Ramutsindela, D. Mickler (Eds.), Africa and the Sustainable Development Goals. Sustainable Development Goals Series. Springer. https://doi.org/10.1007/9783-030-14857-7_10

Blanchard, J.L., Watson, R.A., \& Fulton, E.A. (2017). Linked sustainability challenges and trade-offs among fisheries, aquaculture and agriculture. Nature Ecology \& Evolution, 1, 1240-1249. https:// doi.org/10.1038/s41559-017-0258-8

Bodaghi, B., Palaneeswaran, E., Shahparvari, S., \& Mohammadi, M. (2020). Probabilistic allocation and scheduling of multiple resources for emergency operations; a Victorian bushfire case study. Computers, Environment and Urban Systems, 81, 101479. https://doi.org/10.1016/j.compenvurbsys.2020.101479

Bouma, J. (2015). Reaching out from the soil-box in pursuit of soil security. Soil Science and Plant Nutrition, 61(4), 556-565. https://doi.org/10.1080/00380768.2015.1045403

Bracken, L.J., Cockshut, L., Taylor, J., \& Cotterill, S. (2020). The role of innovation in advancing understanding of hydrological processes. Hydrological Processes, 34, 4404-4416. https://doi.org/10.1002/ hyp. 13890

Brauch, H.G. (2018). Sustainable Peace Through Sustainability Transition as Transformative Science: A Peace Ecology Perspective in the Anthropocene. In H. Brauch, U. Oswald Spring, A. Collins, S. Serrano Oswald (Eds.), Climate Change, Disasters, Sustainability Transition and Peace in the Anthropocene. The Anthropocene: Politik-Economics-Society-Science, vol. 25. Springer. https:// doi.org/10.1007/978-3-319-97562-7_8

Brecha, R. (2019). Electricity Access Threshold for Meeting Non-Energy SDG Targets. European Journal of Sustainable Development, 8(4), 90-100. https://doi.org/10.14207/ejsd.2019.v8n4p90

Brundier, K. (2018). Disasters as opportunities for sustainability: the case of Christchurch, Aotearoa New Zealand. Sustainability Science, 13, 1075-1091. https://doi.org/10.1007/s11625-017-0523-4

Busby, J., Smith, T.G., Krishnan, N., Wight, C., \& Vallejo-Gutierrez, S. (2018). In harm's way: Climate security vulnerability in Asia. World Development, 112, 88-118. https://doi.org/10.1016/j.worlddev.2018.07.007

Celdran, A.H., Perez, M.G., \& Clemente, F.J.G. (2018). Sustainable securing of Medical Cyber-Physical Systems for the healthcare of the future. Sustainable Computing: Informatics and Systems, 19, 138-146. https://doi.org/10.1016/j.suscom.2018.02.010

Chiaramonti, D., \& Maniatis, K. (2020). Security of supply, strategic storage and Covid19: Which lessons learnt for renewable and recycled carbon fuels, and their future role in decarbonizing transport? Applied Energy, 271, 115216. https://doi.org/10.1016/j.apenergy.2020.115216

Cleaveland, S., Sharp, J., Abela-Ridder, B., \& Allan, K.J. (2016). One Health contributions towards more effective and equitable approaches to health in low- and middle-income countries. Phylosophical Transaction B, 372, 20160168. http://dx.doi.org/10.1098/rstb.2016.0168

Cottes, J. (2013). Technological variation and the US renewable fuel standard. Journal of Technology Analysis \& Strategic Management, 26(4),385-399. https://doi.org/10.1080/09537325.2013.851374

Dell'Angelo, J., D'Odorico, P., \& Rulli, M.Ch.(2017). Threats to sustainable development posed by land and water grabbing. Current Opinion in Environmental Sustainability, 26-27, 120-128. http://dx.doi. org/10.1016/j.cosust.2017.07.007

Dolley, J., Marshall, F., Butcher, B., Reffin, J., Robinson, J. A., Eray, B., \& Quadrianto, N. (2020). Analysing trade-offs and synergies between SDGs for urban development, food security and poverty alleviation in 
rapidly changing peri-urban areas: a tool to support inclusive urban planning. Sustainability Science, 15, 1601-1619. https://doi.org/10.1007/s11625-020-00802-0

Eliasson, K., Wibeck, V., \& Neset, T.-S. (2019). Opportunities and Challenges for Meeting the UN 2030 Agenda in the Light of Global Change-A Case Study of Swedish Perspectives. Sustainability, 11, 5221. https://doi.org/10.3390/su11195221

Fanzo, J. (2015). Ethical issues for human nutrition in the context of global food security and sustainable development. Global Food Security, 7, 15-23. http://dx.doi.org/10.1016/j.gfs.2015.11.001

Fennelly, L.J., \& Perry, M.A. (2020). Chapter 35 - Building a Sustainable Culture of Security. In: The Professional Protection Officer, 2 ed. (pp.397-401). https://doi.org/10.1016/B978-0-12-817748-8.00035-3

Fujimori, S., Hasegawa, T., \& Krey, V. (2019). A multi-model assessment of food security implications of climate change mitigation. Nature Sustainability, 2, 386-396. https://doi.org/10.1038/s41893-019-0286-2

Gheuens, J., Nagabhatla, N., Duminda, E., \& Perera, P. (2019). Disaster-Risk, Water Security Challenges and Strategies in Small Island Developing States (SIDS). Water, 11,637.https://doi.org/10.3390/w11040637

Gromek, P. (2020). The Essence of Societal Security in Poland. Scientific Papers of The Main School of Fire Service, Special Issue 1, 185-198.

Gromek, P., \& Sobolewski, G. (2020). Risk-Based Approach for Informing Sustainable Infrastructure Resilience Enhancement and Potential Resilience Implication in Terms of Emergency Service Perspective. Sustainability, 12, 4530. https://doi.org/10.3390/su12114530

Guo, M., \& Song, W. (2019). The growing U.S. bioeconomy: Drivers, development and constraints. New BIOTECHNOLOGY, 49, 48-57.https://doi.org/10.1016/j.nbt.2018.08.005

Horn, P., \& Grugel, J. (2018). The SDGs in middle-income countries: Setting or serving domestic development agendas? Evidence from Ecuador. World Development, 109, 73-84. https://doi.org/10.1016/j. worlddev.2018.04.005

Hoyland, S.A. (2018). Exploring and modeling the societal safety and societal security concepts - A systematic review, empirical study and key implications. Safety Science, 110 Part C, 7-22. https://doi. org/10.1016/j.ssci.2017.10.019

Kakkar, M., Hossain, S.S., \& Abbas, S.S. (2014). One Health: a perspective from the human health sector. Revue Scientifique et Technique, 33(2), 407-412. https://doi.org/10.20506/rst.33.2.2299

Keairns, D.L., Darton, R.C., \& Irabien, A. (2016). The Energy-Water-Food Nexus. Annual Review of Chemical and Biomolecular Engineering, 7, 239-263. https://doi.org/10.1146/annurev-chembioeng-080615-033539

Klimova, A., Rondeau, E., Andersson, K., Porras, J., Rybin, A., \& Zaslavsky, A. (2016). An international Master's program in green ICT as a contribution to sustainable development. Journal of Cleaner Production, 135, 223-239. https://doi.org/10.1016/j.jclepro.2016.06.032

Koh, L.P., \& Ghazoul, J. (2008). Biofuels, biodiversity, and people: Understanding the conflicts and finding opportunities. Biological Conservation, 141,2450-2460. https://doi.org/10.1016/j.biocon.2008.08.005

Korba, M. (2003). Security sector and its reform. Sociologia, 35(5), 433-452. https://www.researchgate. net/publication/288270187_Security_sector_and_its_reform

Kumi, E., Yeboah, T., \& Kumi, Y.A. (2020). Private sector participation in advancing the Sustainable Development Goals (SDGs) in Ghana: Experiences from the mining and telecommunications sectors. The Extractive Industries and Society, 7, 181-190. https://doi.org/10.1016/j.exis.2019.12.008

Lah, O., \& Lah, B. (2018). Pathways Towards Decarbonising the Transportation Sector. In B. Müller, \& 
G. Meyer (Eds.), Towards User-Centric Transport in Europe. Lecture Notes in Mobility. Springer. https://doi.org/10.1007/978-3-319-99756-8_4

Lah, O. (2017). Sustainable development synergies and their ability to create coalitions for low-carbon transport measures. Transportation Research Procedia, 25, 5083-5093. https://doi.org/10.1016/j. trpro.2017.05.495

Lal, R. (2013). Climate-strategic agriculture and the water-soil-waste nexus. Journal of Plant Nutrition and Soil Science, 176, 479-493. https://doi.org/10.1002/jpln.201300189

Lehnert, Ch., Giannopapa, Ch., \& Vaudo, E. (2016). The common objectives of the European Nordic countries and the role of space. Acta Astronautica, 128, 640-649. http://dx.doi.org/10.1016/j.actaastro.2016.08.006

Lemmen, Ch., van Oosterom, P., \& Bennett, R. (2015). The Land Administration Domain Model. Land Use Policy, 49, 535-545. http://dx.doi.org/10.1016/j.landusepol.2015.01.014

Liu, J.-Y., Fujimori, S., Takahashi, K., Hasegawa, Tm., Wu, W., Takakura, J., \& Masui, T. (2019). Environmental Research Letters, 14, 124070. https://doi.org/10.1088/1748-9326/ab59c4

Mabhaudhi, T., Chibarabada, T.P., Petrova Chimonyo, V.G., Murugani, V.G., Pereira, L.M., Sobratee, N., Govender, L., Slotow, R., \& Thembinkosi Modi, A. (2019). Mainstreaming Underutilized Indigenous and Traditional Crops into Food Systems: A South African Perspective. Sustainability, 11, 172. https:// doi.org/10.3390/su11010172

Mary, S., \& Mishra, A.K. (2020). Humanitarian food aid and civil conflict. World Development, 126, 104713. https://doi.org/10.1016/j.worlddev.2019.104713

Massenberg, J.R. (2019). Social values and sustainability: a retrospective view on the contribution of economics. Sustainability Science, 14, 1233-1246. https://doi.org/10.1007/s11625-019-00693-w

Mohandes, B., Hammadi, R.A., Sanusi, W., Mezher, T., \& Khatib, S.E. (2018). Advancing cyber-physical sustainability through integrated analysis of smart power systems: A case study on electric vehicles. International Journal of Critical Infrastructure Protection, 23, 33-48. https://doi.org/10.1016/j. ijcip.2018.10.002

Moreira, L., \& Lopez, M. (2018). Application of triple helix model to eradicate extreme poverty through social innovation and sustainable development: A new challenge for Ecuadorian universities. INTED2018 Proceedings, (pp. 6836-6842). http://dx.doi.org/10.21125/inted.2018.1610

Mulligan, M., van Soesbergen, A., Hole, D.G., Brooks, T.M., Burke, S., \& Hutton, J. (2020). Mapping nature’s contribution to SDG 6 and implications for other SDGs at policy relevant scales. Remote Sensing of Environment, 239, 111671.https://doi.org/10.1016/j.rse.2020.111671

Munang, R.T., Thiaw, I., \& Rivington, M. (2011). Ecosystem Management: Tomorrow's Approach to Enhancing Food Security under a Changing Climate. Sustainability, 3, 937-954; https://doi.org/10.3390/ su3070937

Nuta, I., \& Ciortan, F. (2015). Impact prevention and management of emergency situation for sustainable development. Procedia Economics and Finance, 32, 940-945. https://doi.org/10.1016/S22125671(15)01584-1

Odii, E.C., Ebido, Ch.C., \& Harder, M.K. (2020). A values-based approach for generating localized social indicators for use in sustainability assessment and decision-making: Test case of brownfield soft reuse in Nigeria. Science of The Total Environment, 711, 135045. https://doi.org/10.1016/j.scitotenv.2019.135045

Pérez-Alfocea, F. (2015). Why Should We Investigate Vegetable Grafting? Acta Horticulturae, 1086, 21-29. https://doi.org/10.17660/ActaHortic.2015.1086.1 
Rao, N.Ch., Bathla, S., Kumar, A., \& Jha, G.K. (2018). Agriculture and sustainable development goals: an overview and issues. Agricultural Economics Research Review, 31, 1-7.http://orcid.org/0000-00018920-6598

Rao, N., Mishra, A., Prakash, A., Singh, Ch., Qaisrani, A., Poonacha, P., Vincent, K., \& Bedelian, C. (2019). A qualitative comparative analysis of women's agency and adaptive capacity in climate change hotspots in Asia and Africa. Nature Climate Change, 9, 964-971.https://doi.org/10.1038/s41558-019-0638-y

Report of the Inter agency and Expert Group on Sustainable Development Goal Indicators. UN Economic and Social Council. http://ggim.un.org/knowledgebase/KnowledgebaseArticle51479.aspx Rhinard, M. (2007). Societal security: an emerging role for the European Union. In A. Boin, M. Ekengren, A. Missiroli, M. Rhinard, \& B. Sundelius (Eds.), Building Societal Security in Europe: The EU's Role in Managing Emergencies (pp. 8-21). European Policy Centre (EPC). http://www.societalsecurity. eu/uploads/Articles/EPC\%20Working\%20Paper\%20No.\%2027.pdf\#page=7

Richards, S.J., \& Zaili, J.A. (2020). Contribution of encouraging the future use of biomethane to resolving sustainability and energy security challenges: The case of the UK. Energy for Sustainable Development, 55, 48-55. https://doi.org/10.1016/j.esd.2019.12.003

Roostaie, S., Nawari, N., \& Kibert, C.J. (2019). Sustainability and resilience: A review of definitions, relationships, and their integration into a combined building assessment framework. Building and Environment, 154, 132-144. https://doi.org/10.1016/j.buildenv.2019.02.042

Roy, A., \& Pramanick, K. (2019). Analysing progress of sustainable development goal 6 in India: Past, present, and future. Journal of Environmental Management, 232, 1049-1065. https://doi.org/10.1016/j. jenvman.2018.11.060

Rozhenkova, V., Allmang, S., Ly, S., Franken, D., \& Heymann, J. (2019). The role of comparative city policy data in assessing progress toward the urban SDG targets. Cities, 95, 102357.https://doi.org/10.1016/j. cities.2019.05.026

Scharlemann, J.P.W., Brock, R.C., \& Balfour, N. (2020). Towards understanding interactions between Sustainable Development Goals: the role of environment-human linkages. Sustainability Science, 15, 1573-1584. https://doi.org/10.1007/s11625-020-00799-6

Schleifer, P., \& Sun, Y. (2020). Reviewing the impact of sustainability certification on food security in developing countries. Global Food Security, 24, 100337. https://doi.org/10.1016/j.gfs.2019.100337

Serrano-Tovar, T., Suarez, B.P., Musicki, A., de la Fuente Bencomo, J.A., Cabello, V., \& Giampietro, M. (2019). Structuring an integrated water-energy-food nexus assessment of a local wind energy desalination system for irrigation. Science of the Total Environment, 689, 945-957. https://doi.org/10.1016/j. scitotenv.2019.06.422

Shahbazbegian, M., \& Bagheri, A. (2010). Rethinking assessment of drought impacts: a systemic approach towards sustainability. Sustainability Science, 5, 223-236. https://doi.org/10.1007/s11625-010-0110-4

Shiroyama, H., Yarime, M., Matsuo, M., Schroeder, H., Scholz, R., \& Ulrich, A.E. (2012). Governance for sustainability: knowledge integration and multi-actor dimensions in risk management. Sustainability Science, 7, 45-55. https://doi.org/10.1007/s11625-011-0155-z

Siemiątkowski, P., Tomaszewski, P., Marszałek-Kawa, J., \& Remzer-Płotka, K. (2020). The Assessment of the Efficiency of the Sustainable Development Policy in the Category of Economic Order across Polish Provinces. In K.S. Soliman (Ed.), Sustainable Economic Development and Advancing Education Excellence in the era of Global Pandemic (pp. 9251-9259). International Business Information Management Association (IBIMA). 
Stehfest, E., van Zeist, W.-J., Valin, H., Havlik, P., Popp, A., Kyle, P., Tabeau, A., Mason-D’Croz, D., Hasegawa, T., Bodirsky, B.L., Calvin, K., Doelman, J.C., Fujimori, S., Humpenöder, F., Lotze-Campen, H., van Meijl, H., \& Wiebe, K. (2019). Key determinants of global land-use projections. Nature Communications, 10, 2166. https://doi.org/10.1038/s41467-019-09945-w

Stergiou, Ch., Psannins, K.E., Gupta, B.B., \& Ishibashi, Y. (2018). Security, privacy \& efficiency of sustainable Cloud Computing for Big Data \&IoT. Sustainable Computing: Informatics and Systems, 19, 174-184. https://doi.org/10.1016/j.suscom.2018.06.003

Suk, H., Yadav, A., \& Hall, J. (2018, August 26-29). Scalability considerations in the design of microgrids to support socioeconomic development in rural communities. Proceedings of the 2018 ASME International Design Engineering Technical Conferences \& Computers and Information in Engineering Conference, Quebec City, Canada. https://www.researchgate.net/publication/330405740_Scalability_Considerations_in_the_Design_of_Microgrids_to_Support_Socioeconomic_Development_in_Rural_Communities

Swain, R.B., \& Ranganathan, S. (2021). Modeling interlinkages between sustainable development goals using network analysis. World Development, 138, 105136. https://doi.org/10.1016/j.worlddev.2020.105136

Swensson, L.F.J., \& Tartanac, F. (2020). Public food procurement for sustainable diets and food systems: The role of the regulatory framework. Global Food Security, 25, 100366. https://doi.org/10.1016/j. gfs.2020.100366

Transforming our world: the 2030 Agenda for Sustainable Development. Resolution adopted by the General Assembly on 25 September 2015. https://sustainabledevelopment.un.org/post2015/transformingourworld

The Paris Agreement. (2015). UN.

Tvaronaviciene, M. (2019). Leadership for Critical Infrastructure Protection. In W. Strielkowski (Ed.), Entrepreneurial and Sustainable Academic Leadership: An Introduction. Springer. https://doi. org/10.1007/978-3-030-15495-0_40

UNDRR. (2020). Hazard Definition \& Classification Review. Technical Report. UN Office for Disaster Risk Reduction. https://www.undrr.org/publication/hazard-definition-and-classification-review

van Rees, Ch.B., Rozek Canizares, J., Garcia, G.M., \& Reed, J.M. (2019). Ecological Stakeholder Analogs as intermediaries between freshwater biodiversity conservation and sustainable water management. Environmental Policy and Governance, 29(3). https://doi.org/10.1002/eet.1856

Wæver, O., \& Buzan, B. (1993). Identity, Migration and the New Security Agenda in Europe. Pinter.

Werther-Pietsch, U. (2018). Measuring the Impact of SDGs on International Law - A Nucleus of a Right to Peace? Austrian Journal of Political Science, 47(1), 17-28. https://doi.org/10.15203/ozp.1895. vol47iss 1

Whitcraft, A.K., Becker-Reshef, I., Justice, Ch.O., Gifford, L., Kavvada, A., \& Jarvis, I. (2019). No pixel left behind: Toward integrating Earth Observations for agriculture into the United Nations Sustainable Development Goals framework. Remote Sensing of Environment, 235, 111470. https://doi. org/10.1016/j.rse.2019.111470

WHO. (2019). How to keep people at the centre of health and sustainable development policies.

Witt, A., Jud, A., Finkelhor, D., Brahler, E., \& Fegert, J.M. (2020). Monitoring recent trends: The prevalence of disclosure of sexual abuse in a representative sample of the German population based on indicator 16.2.3 of the UN Sustainable Development Goals (SDG). Child Abuse \& Neglect, 107, 104575. https:// doi.org/10.1016/j.chiabu.2020.104575 
Wolanin, J. (2017). Common Societal Security Culture in the Baltic Sea Region: Basics and the Way Forward. Council of the Baltic Sea States (CBSS) Secretariat. http://www.bsr-secure.eu/wp-content/ uploads/2017/03/Common-Societal-Security-Culture-working-paper.pdf

Yadav, A., Patra, J., \& Yadav, M. (2020). Strategic planning and challenges to the deployment of renewable energy technologies in the world scenario: its impact on global sustainable development. Environment, Development and Sustainability, 22, 297-315. https://doi.org/10.1007/s10668-018-0202-3

Yuk-ping Lo, K. (2018). Securitizing HIV/AIDS: a game changer in state-societal relations in China? Globalization and Health, 14, 50. https://doi.org/10.1186/s12992-018-0364-7

Zhang, J., Liu, H., Yu, G., Ruan, J., \& Chan, F.T.S. (2019). A three-stage and multi-objective stochastic programming model to improve the sustainable rescue ability by considering secondary disasters in emergency logistics. Computers \& Industrial Engineering, 135, 1145-1154. https://doi.org/10.1016/j. cie.2019.02.003 


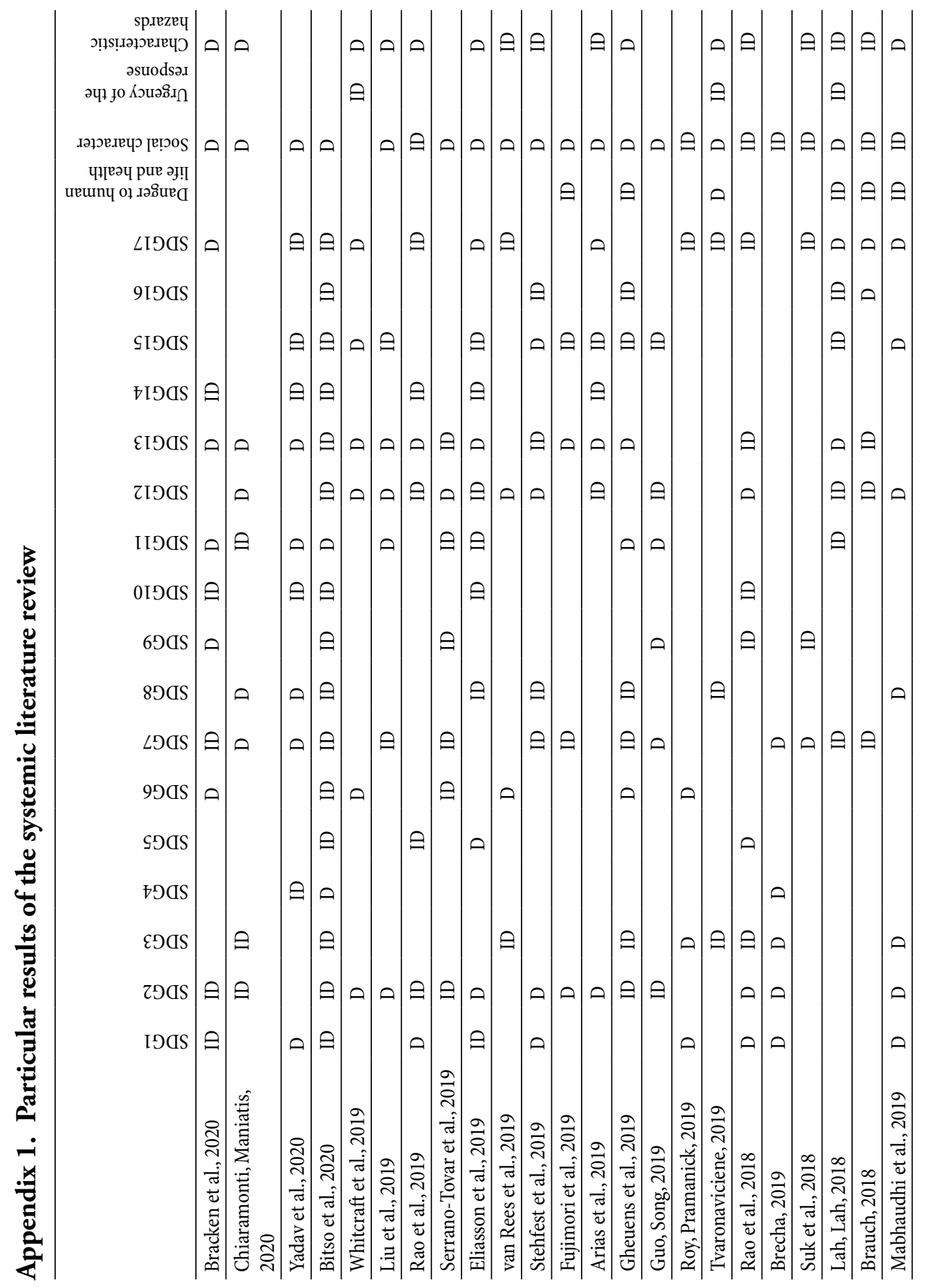




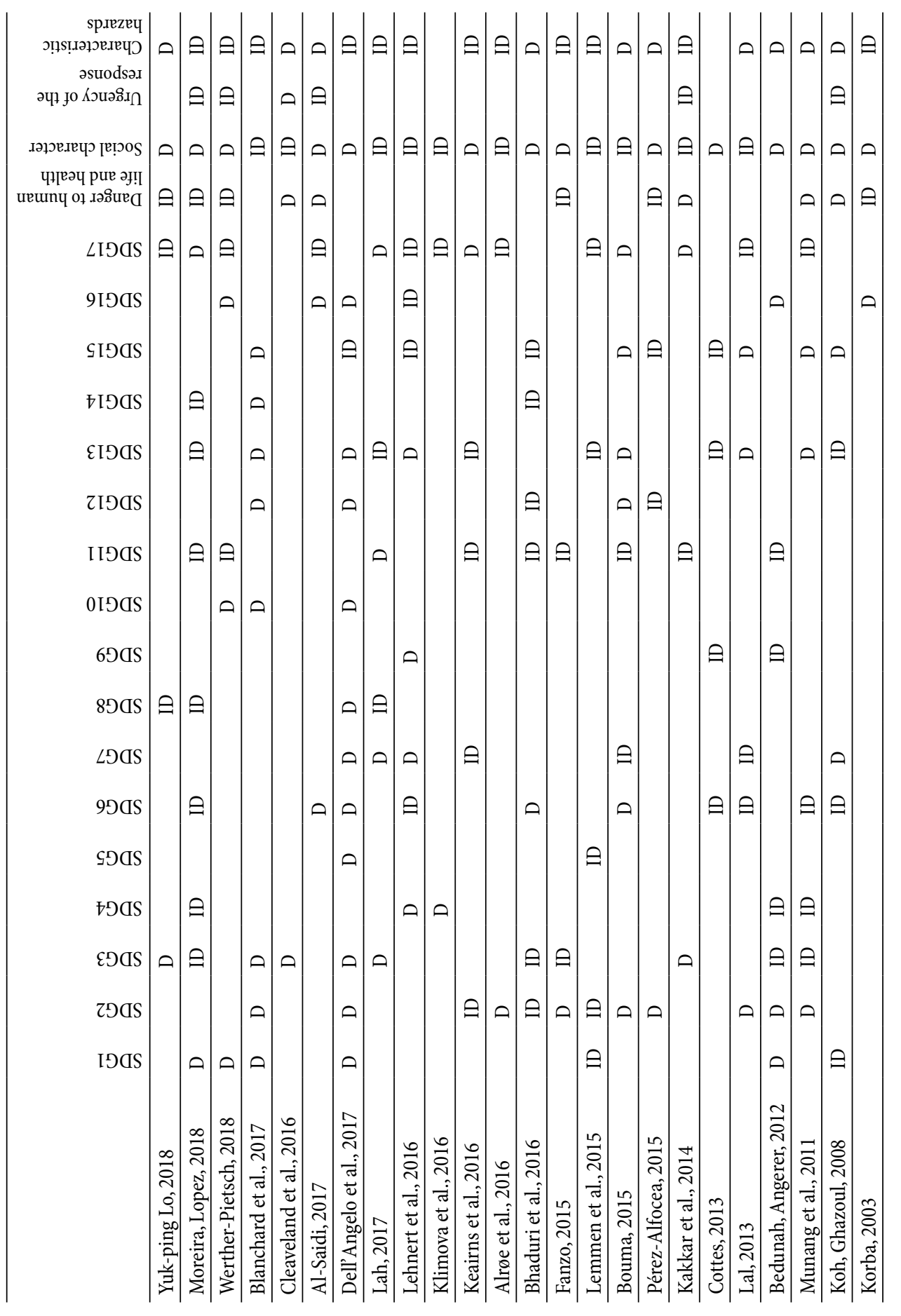

